and the advantages and disadvantages of each, but it certainly exercised my skills in being professional.

Like all helping organisations, particularly those at the end of a telephone, we had our fair share of regular callers. There were also those who rang in to abuse or embarrass but, whatever the reason for calling and even if an abusive caller was faded out, an attempt was made to answer the original question so that some listeners might benefit from the advice given. Fortunately, as the programme became established, these types of call became fewer in number.

One of the major problems in a phone-in programme is balancing audience interest with callers' needs and when psychiatric problems were being discussed it was difficult not to be frustrated by the need to answer calls briefly rather than become involved with a single interesting case. Another difficulty arose from callers who wished a 'second opinion' or to complain about doctors who had been involved in their care. Obviously to criticise a colleague on air could lead to litigation and calls had to be handled with tact and sympathy, perhaps with advice on how to change GP or obtain further help.

Many questions stretch the ability to think on your feet. For instance, in a programme on fears and phobias, mainly spiders, dogs and the like, suddenly to be asked to deal with thunder and lightening phobias (Keraunophobia for the initiated) can upset the well rehearsed behavloural programme that was adapted for each caller. Some questioners ask the near impossible; one wished to know what his rash was possible with a video phone perhaps but very difficult by way of headphones and radio.
Much of the time spent talking on air is education for the listeners and medical terminology, investigations and illnesses have to be described in a simple but not patronising way. (I would suggest that this is an immensely valuable exercise for clinicians who want to improve their communication skills; just listen to a programme like this and see how much understanding and confusion we often leave our patients with). Diagnoses were always made with the proviso that callers should see their own doctors and prescribing, even mild analgesics over the counter, was forbidden without advice to seek guidance from a pharmacist. Initially education included the producers, who wanted a programme with proper medical terminology which, it was explained to them, would not benefit the thousands of listeners they hoped to attract.

Alas, my spell of sitting in a dimly lit, often chilly, studio, full of knobs, dials, CDs and charts has come to an end. I will not have to spend an hour each way on the motorway getting to and from studios of plushness that increased as the company grew financially. The radio company no longer feels that our programme fits their current image and so they have pulled the plug on us. Above all I think that this unique experience has given me a great deal of understanding about how poor our communication with patients often is, and how little they understand of their anatomy and physiology, illnesses, investigations and treatment.

I also know now how easy it is, with a little time and willingness to sit and listen, to put all these things in plain English and make them less worrying.

Lindsey Kemp, Senior Registrar, Medway Hospttal, Gullingham, Kent ME7 5NY

\title{
Application of psychoanalysis to the arts
}

Following a performance of the Royal Shakespeare Company's production of King Lear at the Barbican Theatre, London EC2 on 21 June 1994 at 7 p.m. there will be an evening of discussion on 23 June 1994 at 8.15 p.m. between Robert Stephens (King Lear), Simon Russell Beale (Edgar) and Mary Twyman and Marcus Johns (psychoanalysts) at the Edward Lewis
Theatre, Windeyer Building, 46 Cleveland Street, London W1. Prices: $£ 32.00$ to include stalls seat and discussion, $£ 27.00$ to include circle seat and discussion, $£ 10.00$ discussion only. Further information: The Executive Secretary, The Institute of Psycho-Analysis, 63 New Cavendish Street, London W1M 7RD (telephone 071580 4952). 